\title{
DOES ASSET QUALITY MATTER IN RELATIONSHIP BETWEEN BANK CAPITAL ON LENDING GROWTH?
}

\author{
Ahmad Aziz Putra Pratama \\ Master of Science in Management, Department of Management, \\ Faculty of Economics and Business, Airlangga University \\ Jl. Airlangga No. 4-6, Surabaya 60286, Indonesia
}

\begin{abstract}
Mostly, loans are important source of income for banks and capital is used to absorb shocks during a bank's worst periods. Credit risk is a major concern for the banking industry as the ratio of bad loans increases. The purpose of this research examines the effect of bank capital on lending growth with moderation of asset quality of banking sector listed in Indonesia Stock Exchange (IDX). This study used Fixed Effect Model. Data obtained from the company's financial report published in 2009-2018 period. Dependent variable in this research is lending growth proxied with Net Loan Growth. Independent variable used bank capital proxied with Capital Adequacy Ratio (CAR). Moderating Variable in this research used asset quality proxied with Non Performing Loan (NPL). In addition, controlling variable in this study are liquidity level, firm size and bank performance. The results showed that bank capital has a significant positive effect on lending growth, while the bad asset quality mitigates the positive effect of bank capital on lending growth. This results are in line with policies that have been made by Otoritas Jasa Keuangan (OJK) about maintaning capital adequacy ratio and non performing loan.
\end{abstract}

Keywords: Lending Growth; Net Loan Growth; Bank Capital; Asset Quality; Lending Behavior

Cite this Article: Ahmad Aziz Putra Pratama, Does Asset Quality Matter in Relationship Between Bank Capital on Lending Growth?, International Journal of Management, 10 (5), 2019, pp. 38-47.

http://iaeme.com/Home/issue/IJM?Volume $=10 \&$ Issue $=5$

\section{INTRODUCTION}

Banks are part of the instruments of banking (Moussa \& Chedia, 2016; Setiawan \& Pratama, 2019). Banks are the part of financial institutions with an intermediary function that bridges those who need funds and those who have more funds (Latumaerissa, 2014). The bank is one of the financial institutions whose business operations collect funds from third parties in a bank deposit and give it back to those who need it in the form of credit or loans and other forms in order to facilitate economic flows (Rivai, Basir, Sudarto, \& Veithzal, 2013). Exactly, credit is 
literally the granting of funds from the excess funds to those who need funds based on the trust of both parties (Rose \& Hudgins, 2013). The credit function provides services to the agent who need funds and improving the business sector (Latumaerissa, 2014). The biggest source of income for a bank business comes from the contribution of the large number of loans extended (Berger \& Bouwman, 2013; Moussa \& Chedia, 2016). Banks in Indonesia still use the credit business sector as their main source of income (Junaidi, Sulastri, Isnurhadi, \& Adam, 2019; Raharjo, 2014; Setiawan \& Pratama, 2019; Subandi \& Ghozali, 2013; Thalib, 2016). Better value of income margins can be obtained through effective and efficient management (Raharjo, 2014; Rivai et al., 2013).

Loan has an important role in the operations of a bank (Bayoumi \& Melander, 2008). The biggest source of income for a bank business comes from the contribution of the large number of loans extended (Berger \& Bouwman, 2013; Moussa \& Chedia, 2016). Banks in Indonesia still use the credit business sector as their main source of income (Junaidi et al., 2019; Raharjo, 2014; Setiawan \& Pratama, 2019; Subandi \& Ghozali, 2013; Thalib, 2016). Better value of income margins can be obtained through effective and efficient management (Raharjo, 2014; Rivai et al., 2013). As an intermediary institution, banks must be able to manage the availability of owned capital so that there is no shortage of funds in carrying out their business activities (Kim \& Sohn, 2017). Bank capital adequacy is an important concern because it will affect the operational activities of a bank (Berger \& Bouwman, 2013; Berrospide \& Edge, 2010; Carlson, Shan, \& Warusawitharana, 2013; Cornett, McNutt, Strahan, \& Tehranian, 2011; Gambacorta \& Marques-Ibanes, 2011; Kim \& Sohn, 2017).

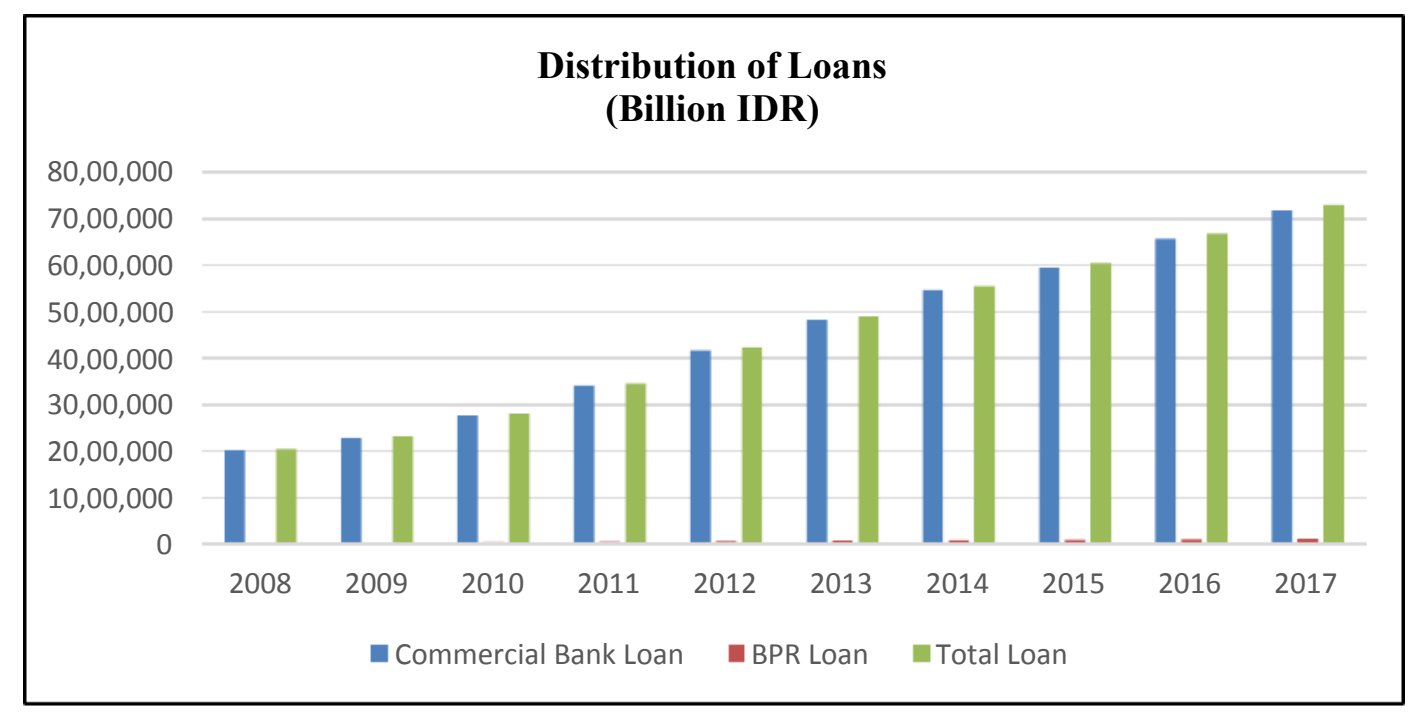

Figure 1.1 Distribution of loans in Indonesia during 2008-2017 period

Traditional monetary theory has largely ignored the role of bank equity (Van den Heuvel, 2002). Bank-centered accounts of how monetary policy affects the real economy usually focus on the role of reserves and reserve requirements in determining the volume of demand deposits and, in the case of the bank lending channel, bank loans. Despite this evidence, the role of bank capital and capital requirements in the monetary transmission mechanism has received much less attention. The traditional interpretation of the "bank lending channel" focuses on the effects of reserve requirements on demand deposits, while no attention is paid to bank equity. So, bank capital is interpreted as an "irrelevant" balance-sheet item (Gambacorta \& Marques-Ibanes, 2011; Van den Heuvel, 2002). It was only recently that bank capital has been taken into account in the context of the "bank lending channel". 
For bank, the word capital has a special meaning. The capital accounts play several roles in supporting the daily operations and ensuring the long run viability of banks. Capital performs such indispensable functions as providing a cushion of protection against risk and promoting public confidence in the long term viability of a banks. Moreover, capital has become the centerpiece of supervision and regulation today. The lever that regulators can pull whenever the alarm bell sounds in an effort to prevent the collapse of a bank. Indeed, it is difficult to name anything else on the balance sheet of bank that performs so many vital tasks.

Earlier empirical investigations in Indonesia concerning determinant of bank loan (Satria \& Subegti, 2010), the effect of bank capital on performance (Raharjo, 2014; Subandi \& Ghozali, 2013; Thalib, 2016), bank risk (Kamaludin, Darmansyah, \& Usman, 2015) and sustainability growth rate (Junaidi et al., 2019). Previous research only examined the effect of bank capital on lending, but did not recognized moderating effect of asset quality on lending growth. The novelty of this research is moderating effect of asset quality in relationship between bank capital on lending growth. This study proved that bad asset quality mitigates the positive effect of bank capital on lending growth. This finding proved "risk absorption" theory (Berger \& Bouwman, 2009; Diamond \& Rajan, 2001). This results are in line with policies that have been made by Otoritas Jasa Keuangan (OJK) about maintaning capital adequacy ratio (minimum 8\%) and non performing loan (maximum 5\%). In addition, This findings suggests that bank must consider to manage its capital and asset quality before make future lending decision. Empirical studies on this research can be can be used as a consideration of the central bank to establish policies relating to bank asset quality, lending and capital adequacy that must be owned.

\section{HYPOTHESES DEVELOPMENT}

\subsection{Bank Capital on Lending Growth}

There are some important connections between the level of bank capital and the strength of the lending channel. This study hypotheses can be explained based on the "risk absorption" theory, referred to by (Berger \& Bouwman, 2009). The effect of bank capital on lending is positive under the "risk absorption" theory because bank capital enhances bank's risk bearing capacity. Most studies focus on the linear relationship between bank capital ratio and lending (Berrospide \& Edge, 2010; Francis \& Osborne, 2012; Gambacorta \& Mistrulli, 2004; Kim \& Sohn, 2017; Moussa \& Chedia, 2016; Rabab'ah, 2015; Satria \& Subegti, 2010; Setiawan \& Pratama, 2019), performance (Raharjo, 2014; Subandi \& Ghozali, 2013; Thalib, 2016), risk-taking (Kamaludin et al., 2015), sustainability growth rate (Junaidi et al., 2019) or examine whether a structural change occurs following external shocks (Cornett et al., 2011; Gambacorta \& Marques-Ibanes, 2011; Ivashina \& Scharfstein, 2010). Brei et al. (2013) and Carlson et al. (2013), however, capture the nonlinear effects of a change in the capital ratio on loan growth.

According to Berrospide \& Edge (2010), Gambacorta \& Mistrulli (2004), Kim \& Sohn (2017) proved that the value of CAR has a significant positive effect on lending growth. The greater the amount of capital, the higher financial ability to anticipate emergence of losses caused by large amount of credit given to debtors. Bank capital has a psychological impact on increasing banking confidence in providing credit. This arises because banks have more ability to overcome the risk of bad credit that may occur in the future due to investments in risk assets. Berger \& Bouwman (2013) emphasizes the role of capital as a buffer to absorb shocks to earnings. Gambacorta \& Mistrulli (2004) find that excess capital exerts a significantly positive effect on lending and that the effects of monetary policy and output shocks on bank lending differ depending upon the level of bank capitalization. Francis \& Osborne (2012) show that banks increase their target capital ratios when capital requirements increase, and vice versa. Based on the explanation above, the research hypotheses is: 
$\mathrm{H}_{1}$ : Bank capital has a positive effect on lending growth.

\subsection{Asset Quality as Moderating Variable}

Banks that have high capital will become lowering their loans due to high bad asset quality as indicated by the increasing value of non performing loans (NPL). NPL shows credit quality related to default risk. The ratio of noncurrent loans to total loans reflects the quality of the bank loan portfolio. While this ratio is a backward-looking measure of loan quality. NPL reflect the health of banks through the amount of bad loans. The higher the level of NPL, the worse the portfolio quality is. Banks reduce lending by more substantial degrees as loan quality worsens. The greater of bad loans cause the loan uncollectible and the impact on bank losses. Nonperforming loans will reduce the value of assets owned, resulting in erosion of bank capital. There is a need for more capital injections if the value of bad loans and investments in risky assets becomes higher (Kim \& Sohn, 2017). When banks have high NPL, banks are more likely to withhold credit in order to reduce the credit risk of loans. Banks that have a lot of bad loans will maintain their capital adequacy ratio in order to be able to cover declining value of assets due to investments in risk assets that cause bank losses. Based on the explanation above, the research hypotheses is:

$\mathrm{H}_{2}$ : The positive effect of bank capital will be mitigated by bad asset quality

\subsection{Control Variables on Lending Growth}

This study use the additional bank-specific characteristic variables that are considered in the literature as important control variables that affect bank lending. This research used three control variables such as liquidity level, firm size and bank performance. Liquidity level depicts the bank's ability to absorb liquidity shocks. More liquid banks are able to provide more lending by drawing on their stock of liquid assets (Moussa \& Chedia, 2016). On the other hand, higher liquid assets reduces the proportion of loans granted (Rabab'ah, 2015). According to the "too big to fail" theory, large banks have incentives to take more risk and supplying of more credit (Kim \& Sohn, 2017). However, large banks can diversify their portfolio in various activities. From this perspective, the size effect can be negative (Berger \& Udell, 2006; Kim \& Sohn, 2017). Banks with high profitability have strong balance sheets because profitability is related to the quality and quantity of capital ratios. In contrast, a higher profitability might supply fewer loans to improve the quality of assets.

\section{METHOD, DATA, AND ANALYSIS}

Quantitative approach is used in this research because the data is presented in the form of numbers or nominal with systematic measurement through purposive sampling at 40 banks that listed on Indonesia Stock Exchange (IDX) in 2009-2018 period with 355 observations. Purposive sampling criteria used in this study are banking sector public companies listed on the Indonesia Stock Exchange (IDX), based on conventional principles and not sharia, the financial statements provide complete data, presented in rupiah currency (IDR), and does not include banking companies with incomplete data.

Measurements were made based on the company's financial statements. Research conducted to test hypotheses with statistical tools and measured data to produce general inference. This study used Fixed Effect Model with STATA Statistics Data Analysis 14.2 Special Edition Version as a statistical tool. Kim \& Sohn (2017) recommends Fixed Effects Estimators as superior alternatives. Roodman (2009) also recommends Fixed Effects Estimators as superior alternatives to dynamic system Generalized Method of Moment (GMM). The Fixed Effects Method has been extensively used in the literature (Berrospide \& Edge, 2010; Cornett et al., 2011; Francis \& Osborne, 2012). As argued by Brei et al. (2013), nonrandomly selecting a 
sample from the population of banks is also consistent with the choice of Fixed Effects Estimations. Sample selection and operational definitions of variables can be seen in Table 1 and Table 2.

\begin{tabular}{|c|c|}
\hline \multicolumn{2}{|c|}{ Table 1. Sample selection } \\
\hline Sample & Total \\
\hline All observation & 400 \\
\hline Lagged observation (-) & 40 \\
\hline Outlayer (-) & 5 \\
\hline Total observation & $\mathbf{3 5 5}$ \\
\hline \multicolumn{2}{|c|}{ Note: Measurement through purposive sampling } \\
\hline
\end{tabular}

\begin{tabular}{|c|c|c|c|}
\hline Variable & \multicolumn{2}{|c|}{ Operational Definition } & Measurement \\
\hline Lending growth & $\begin{array}{l}\text { Real growth rate of net } \\
\text { loans }\end{array}$ & LOAN & $\begin{array}{c}\left(\text { Net } \operatorname{loan}_{t}-\text { net loan }\right. \\
\text { to-1 }) / \text { net } \\
\text { loan }_{t-1}\end{array}$ \\
\hline Bank capital & $\begin{array}{c}\text { Value of capital adequacy } \\
\text { ratio }\end{array}$ & CAR & $\begin{array}{c}\text { Bank capital/risk weighted } \\
\text { assets }\end{array}$ \\
\hline Loan quality & Noncurrent loans to loans & NPL & Noncurrent loans/total loans \\
\hline Liquidity level & $\begin{array}{l}\text { Ratio of liquid asset to total } \\
\text { assets }\end{array}$ & LIQ & Total liquid assets/total assets \\
\hline Firm size & Logarithm of total assets & SIZE & logarithm of total assets \\
\hline $\begin{array}{c}\text { Bank } \\
\text { performance }\end{array}$ & Return on total assets & ROA & Net income/total assets \\
\hline
\end{tabular}

The analysis model in this study was formulated as follows:

$\operatorname{LOAN}_{i, t}=\beta_{0}+\beta_{1} C A R_{i, t-1}+\beta_{2} N P L_{i, t-1}+\beta_{3}(C A R * N P L)_{i, t-1}+\beta_{4} L I Q_{i, t-1}+\beta_{5} \operatorname{SIZE}_{i, t-1}+\beta_{5} R O A_{i, t-1}+e_{i, t}$

\section{RESULTS AND DISCUSSION}

This research used 238 observation (exclude outlier data). Table 3 showed a statistical description of the research sample data. Table 4 showed the regression results from panel data processing.

\begin{tabular}{|c|c|c|c|c|c|}
\hline \multicolumn{7}{|c|}{ Table 3. Descriptive statistics results } \\
\hline Variabel & N & Minimum & Maximum & Mean & Standard Deviation \\
\hline LOAN & 355 & -0.3641 & 1.9981 & 0.2354 & 0.2993 \\
\hline CAR & 355 & 0.0802 & 0.8749 & 0.1987 & 0.0967 \\
\hline NPL & 355 & 0.0001 & 0.1228 & 0.0285 & 0.0217 \\
\hline LIQ & 355 & 0.1094 & 0.7004 & 0.3101 & 0.1561 \\
\hline SIZE & 355 & 11.3994 & 15.1216 & 13.891 & 0.8541 \\
\hline ROA & 355 & -0.1173 & 0.0390 & 0.0127 & 0.0184 \\
\hline
\end{tabular}

The variable of lending growth (LOAN) has an average of $23.54 \%$ shows that the high level of credit disbursed by banks every year. The bank capital variable (CAR) has an average of $19.87 \%$ shows the bank capital in this study can be categorized as healthy banks because it has value more than $8 \%$ (POJK Number 11/POJK.03/2016). The loan quality variable (NPL) has an average of 0.0285 less than 5\% (POJK Nomor 1/POJK.03/2019) which implies that the average bank in this research sample has better loan quality .The variable bank liquidity level (LIQ) has an average of $31.01 \%$ implies that the banks have sufficient liquidity to manage risk. 
The average firm size variable (SIZE) is 13.891. Bank performance variable (ROA) has an average of $1.27 \%$ indicates that banks in Indonesia have relatively low performance.

\begin{tabular}{|c|c|c|}
\hline \multicolumn{3}{|c|}{ Table 4. Panel data regression test results } \\
\hline Dependent variable: & \multicolumn{2}{|c|}{ LOAN (Lending growth) } \\
\hline Regression: & No Moderation & Moderated Analysis \\
\hline Analysis model: & (1) & $(2)$ \\
\hline \multirow[t]{2}{*}{ Intercept } & $* *-1.942$ & $*_{-2.122}$ \\
\hline & $(0.021)$ & $(0.067)$ \\
\hline \multirow[t]{2}{*}{ CAR (Bank capital) } & $* * * 1.383$ & $* * 1.846$ \\
\hline & $(0.008)$ & $(\mathbf{0 . 0 3 4 )}$ \\
\hline \multirow[t]{2}{*}{ NPL (loan quality) } & & $*-2.312$ \\
\hline & & $(0.082)$ \\
\hline \multirow[t]{2}{*}{ CAR*NPL } & & $* * *-7.321$ \\
\hline & & $(0.008)$ \\
\hline \multirow[t]{2}{*}{ LIQ (Liquidity level) } & $* * * 0.072$ & $* * 0.177$ \\
\hline & $(0.007)$ & $(0.019)$ \\
\hline \multirow[t]{2}{*}{ SIZE (Firm size) } & $* * * 0.178$ & $* * * 0.188$ \\
\hline & $(0.005)$ & $(0.000)$ \\
\hline \multirow[t]{2}{*}{ ROA (Bank performance) } & $* * * 4.261$ & $* * * 4.349$ \\
\hline & $(0.000)$ & $(0.000)$ \\
\hline Fixed Effect & Yes & Yes \\
\hline Observations & 355 & 355 \\
\hline R-Squared & 0.214 & 0.285 \\
\hline \multicolumn{3}{|c|}{ Source: STATA Statistics Data Analysis 14.2 Special Edition Version } \\
\hline
\end{tabular}

Based on the results of the regression test, the bank capital proxy by CAR has a significant positive effect on lending growth (coefficient 0.1383 with a significance $<0.01$ ). This result accept H1. The higher the bank's capital, the greater the amount of credit that can be distributed. Futhermore, interaction between CAR and NPL has a significant negative effect on lending growth (coefficient -7.321 with a significance $<0.01$ ).

This result accept $\mathbf{H}_{2}$. Bad asset quality mitigates the positive effect of bank capital on lending growth.

$\mathrm{R}$-squared value in Model 1 is 0.214 indicates that all independent variables in model are jointly able to explain the variation in the dependent variable of $21.4 \%$, while $78.6 \%$ is explained by other variables outside this model. R-squared value in Model 2 is 0.285 indicates that all independent variables in model are jointly able to explain the variation in the dependent variable of $28.5 \%$, while $71.5 \%$ is explained by other variables outside this model.

\subsection{Relationship between Bank Capital and Lending Growth}

Capital is part of a very crucial thing for a bank because the health and security of a bank is judged by its capital adequacy. The size of capital indicates the level of bank's ability to finance assets that contain risks (Gambacorta \& Mistrulli, 2004). Banks that have sufficient capital will be better able to cover the value of the declining assets resulting from bank losses (Kim \& Sohn, 2017). Declining bank's profit occurred due to the amount of losses incurred by banks from investing in risk assets (Carlson et al., 2013). Capital is used as a buffer for the bank's 
operational activities against possible losses from the occurrence of bad loans (Ivashina \& Scharfstein, 2010). The greater capital indicates that the bank is getting healthier (Latumaerissa, 2014). Banks that have high capital will be better able to anticipate losses caused by increasing the amount of lending (Van den Heuvel, 2002). With better anticipation of losses, banks will be more daring to extend larger amounts of credit (Carlson et al., 2013).

Capital performs such indispensable functions as providing a cushion of protection against risk and promoting public confidence in the long term viability of a financial firm. Moreover, capital has become the centerpiece of supervision and regulation (Rose \& Hudgins, 2013). The capital accounts play several roles in supporting the daily operations and ensuring the long run viability of financial firms. In the first place, capital provides a cushion against the risk of failure by absorbing financial and operating losses until management can address the institution's problems and restore its profitability. Second, capital provides the funds needed to charter, organize and operate a financial firm before other sources of funds come flowing in. Third, capital promotes public confidence and reassures creditors concerning an institution's financial strength. Capital must also be strong enough to reassure borrowers that a lending institution will be able to meet their credit needs even if the economy turns down. Fourth, capital provides funds for development of new services and facilities. Most financial service providers eventually outgrow the facilities they start with. An infusion of additional capital will permit a financial firm to expand into larger quarters or build additional branch offices in order to keep pace with its expanding market and follow its customers. Fifth, capital serves as a regulator of growth, helping to ensure that growth is sustainable in the long run.

Capital adequacy is needed if in the future there is bad credit that will reduce the value of assets, then what is reduced on the liability side is bank capital itself (Setiawan \& Pratama, 2019). Bank capital will be eroded because it is not possible the bank will reduce third party funds (deposits). Banks must reduce their own capital rather than their deposits (Rose \& Hudgins, 2013). If the bank reduces their deposits, the depositors will not trust the bank. From this point of view, banks are considered unable to manage their risks and depositors will suffer losses due to declining value of their deposits. If the bank has a capital adequacy exceeding the requirements, the bank is considered to be better able to deal with credit risk.

\subsection{Moderating Effect of Asset Quality in Relationship between Bank Capital and Lending Growth}

NPL reflect the health of banks through the amount of bad loans. Banks that have high capital will become lowering their loans due to high bad asset quality as indicated by the increasing value of non-performing loans (NPL). The greater noncurrent loans cause the loan uncollectible and the impact on bank losses. When banks have high NPL, banks are more likely to withhold their lending in order to reduce the credit risk of loans.

Maintaining credit quality is very important in making a profit. It is necessary to have an analysis of the prospective debtor so that the credit given is classified as healthy and current loans (Rose \& Hudgins, 2013). Provision of credit without considering the level of credit quality can cause future losses. Nonperforming loans will reduce the value of assets owned, resulting in erosion of bank capital. Banks reduce lending by more substantial degrees as loan quality worsens. There is a need for more capital injections if the value of bad loans and investments in risky assets becomes higher (Kim \& Sohn, 2017). When banks have high NPL, banks are more likely to withhold credit in order to reduce the credit risk of loans. Banks that have a lot of bad loans will maintain their capital adequacy ratio in order to be able to cover declining value of assets due to investments in risk assets that cause bank losses. 


\subsection{Effect of Control Variables on Lending Growth}

Liquidity level, firm size and bank performance have significant positive effect on lending growth. Liquidity level depicts the bank's ability to absorb liquidity shocks. In theory, the higher liquidity ratio indicates that the bank is in a better position to meet its stochastic withdrawals (Chagwiza, 2014). More liquid banks are able to provide more lending by drawing on their stock of liquid assets (Moussa \& Chedia, 2016). According to the "too big to fail" theory, large banks have incentives to take more risk amid high expectations of government bailout to prevent systemic risk, thereby enabling the supplying of more credit (Kim \& Sohn, 2017). The large banks benefit from economies of scale which reduces the cost of production and information gathering (Moussa \& Chedia, 2016). Furthermore, banks with high profitability are likely to have strong balance sheets because profitability is related to the quality and quantity of capital ratios. Thus, a positive relationship between profitability and bank lending (Moussa \& Chedia, 2016).

\section{CONCLUSION}

This study proved "risk absorption" theory on the relationship between bank capital and liquidity creation. The effect of bank capital on lending is positive under the "risk absorption" theory because bank capital enhances bank's risk bearing capacity. The higher the bank's capital, the greater the amount of credit that can be distributed. The novelty of this research examines the moderating effect of asset quality in relationship between bank capital on lending growth. The result proved that the positive effect of bank capital will be mitigated by bad asset quality. This findings are in line with policies that have been made by Otoritas Jasa Keuangan $(O J K)$ about maintaning mininum capital adequacy ratio $(8 \%)$ and non performing loan (maximum 5\%).

Bank management needs to pay attention to manage capital for measuring the ability of banks to provide loans and asset quality. Banks that want to extend their credit need to pay attention to these capital variables and managing their risk. With considering this condition, banks have greater ability to extend more loans. By analyzing capital adequacy and asset quality properly, banks can managed their risk very well. Investors can use the capital reference in assessing bank's health. This information can be used by investors as a reference in determining investment choices in banking sector.

Limitation of this study lies in the use of samples that only bank listed on Indonesia Stock Exchange (IDX). Next study may include non-go public and private bank. Better sample might represent population characteristics. the greater level of confidence desired, the more samples are needed. Further research will be even better if dividing the sample studied based on bank's size. Suggestions for future researchers to add interval period, included crisis period or adding factors that affect lending growth from the external side of the banking such as macroeconomic factors so that the analysis can provide more accurate inference.

\section{REFERENCES}

[1] Bayoumi, T., \& Melander, O, Credit Matters: Empirical evidence on U.S. macro-financial linkages. In International Monetary Fund (No. 08)., 2008

[2] Berger, A. N., \& Bouwman, C. H. S.Bank liquidity creation. Review of Financial Studies, 22(9), 3779-3837. https://doi.org/10.1093/rfs/hhn104,2009

[3] Berger, A. N., \& Bouwman, C. H. S. (2013). How does capital affect bank performance during financial crises? Journal of Financial Economics, 109(1), 2013, pp 146-176 
Does Asset Quality Matter in Relationship Between Bank Capital on Lending Growth?

[4] Berger, A. N., \& Udell, G. F. (2006). A more complete conceptual framework for SME finance. Journal of Banking and Finance, 30(11), 2006, pp 2945-2966. https://doi.org/10.1016/j.jbankfin.2006.05.008

[5] Berrospide, J. M., \& Edge, R. M., The effects of bank capital on lending: What do we know, and what does it mean? Finance and Economics Discussion Series, 2010, pp 1-48.

[6] Brei, M., Gambacorta, L., \& von Peter, G, Rescue packages and bank lending. Journal of Banking and Finance, 37(2), 2013, pp 490-505. https://doi.org/10.1016/j.jbankfin.2012.09.010

[7] Carlson, M., Shan, H., \& Warusawitharana, M, Capital ratios and bank lending: A matched bank approach. Journal of Financial Intermediation, 22(4), 2013, pp 663-687. https://doi.org/10.1016/j.jfi.2013.06.003

[8] Chagwiza, W, Zimbabwean commercial banks liquidity and its determinants. International Journal of Empirical Finance, 2(2), 2014, pp 52-64.

[9] Cornett, M. M., McNutt, J. J., Strahan, P. E., \& Tehranian, H. (2011). Liquidity risk management and credit supply in the financial crisis. Journal of Financial Economics, 101(2), 2011, pp 297-312. https://doi.org/10.1016/j.jfineco.2011.03.001

[10] Diamond, D. W., \& Rajan, R. G, Liquidity risk, liquidity creation, and financial fragility: A theory of banking. Journal of Political Economy, 109(2), 287-327. https://doi.org/10.1086/319552

[11] Francis, W. B., \& Osborne, M, Capital requirements and bank behavior in the UK: Are there lessons for international capital standards? Journal of Banking and Finance, 36(3), 2012, pp 803-816. https://doi.org/10.1016/j.jbankfin.2011.09.011

[12] Gambacorta, L., \& Marques-Ibanes, D, The bank lending channel: Lessons from crisis. Economic Policy, (1), 2011, pp 135-182.

[13] Gambacorta, L., \& Mistrulli, P. E, Does bank capital affect lending behavior? Journal of Financial Intermediation, 13(4), 200, pp 436-457. https://doi.org/10.1016/j.jfi.2004.06.001

[14] Ivashina, V., \& Scharfstein, D, Bank lending during the financial crisis of 2008. Journal of Financial Economics, 97(3), 2010, pp 319-338.

https://doi.org/10.1016/j.jfineco.2009.12.001

[15] Junaidi, S., Sulastri, S., Isnurhadi, I., \& Adam, M, Liquidity, asset quality, and efficiency to sustainable growth rate for banking at Indonesia Stock Exchange. Jurnal Keuangan Dan Perbankan, 23(2), 2019, pp 308-319. https://doi.org/10.26905/jkdp.v23i2.2699

[16] Kamaludin, Darmansyah, \& Usman, B, Determinan non performing loan (NPL) pada industri perbankan (Bukti empiris perusahaan Go Publik di Bursa Efek Indonesia). Jurnal Aplikasi Manajemen, 13(4), 2015, pp 547-556.

[17] Kim, D., \& Sohn, W, The effect of bank capital on lending: Does liquidity matter? Journal of Banking and Finance, 77, 2017, pp 95-107.

https://doi.org/10.1016/j.jbankfin.2017.01.011

[18] Latumaerissa, J. R, Manajemen bank umum. Jakarta: Mitra Wacana Media, 2014

[19] Moussa, M. A. Ben, \& Chedia, H, Determinants of bank lending: Case of Tunisia. International Journal of Finance and Accounting, 5(1), 2016, 27-36. https://doi.org/10.5923/j.ijfa.20160501.04

[20] POJK. Peraturan Otoritas Jasa Keuangan Nomor 11/POJK.03/2016 Tentang Kewajiban Penyediaan Modal Minimum Bank Umum. , (2016).

[21] POJK. POJK Nomor 1/POJK.03/2019 Tentang Penerapan Fungsi Audit Intern Pada Bank Umum. , (2019). 
[22] Rabab'ah, M, Factors affecting the bank credit: An empirical study on the Jordanian commercial banks. International Journal of Economics and Finance, 7(5), 2015, pp 166178. https://doi.org/10.5539/ijef.v7n5p166

[23] Raharjo, P. G, Faktor determinan marjin bunga bersih bank pembangunan daerah Di Indonesia: Suatu studi data panel. Jurnal Keuangan Dan Perbankan, 18(1), 2014, pp 105119.

[24] Rivai, V., Basir, S., Sudarto, S., \& Veithzal, A. P, Commercial bank management: Manajemen perbankan dari teori ke praktik (1st ed). Jakarta: Rajawali Pers, 2013

[25] Roodman, D, How to do xtabond2: An introduction to difference and system GMM in Stata. Stata Journal, 9(1), 2009, pp 86-136.

[26] Rose, P. S., \& Hudgins, S. C, Bank management \& financial services (9th ed). New York: McGraw-Hill Education, 2013

[27] Satria, D., \& Subegti, R. B, Determinasi penyaluran kredit bank umum di Indonesia periode 2006-2009. 14(3), 2010, pp 415-424.

[28] Setiawan, R., \& Pratama, A. A. P, Modal, tingkat likuiditas bank, NPL dan pertumbuhan kredit perbankan Indonesia. Matrik: Jurnal Manajemen, Strategi Bisnis Dan

Kewirausahaan, 13(1), 2019, pp 96-107.

https://doi.org/https://doi.org/10.24843/MATRIK:JMBK.2019.v13.i01.p10

[29] Subandi, \& Ghozali, I, Determinan efisiensi dan dampaknya terhadap kinerja profitabilitas industri perbankan di Indonesia. Jurnal Keuangan Dan Perbankan, 17(1), 2013, pp 123 135.

[30] Thalib, D, Intermediasi, struktur modal, efisiensi, permodalan dan risiko terhadap profitabilitas bank. Jurnal Keuangan Dan Perbankan, 20(1), 2016, pp 116-126. https://doi.org/10.26905/jkdp.v20i1.155

[31] Van den Heuvel, S. J, Does bank capital matter for monetary transmission? Federal Reserve Bank of New York Economic Policy Review, (1), 2002, pp 259-265.

[32] M.Rajeswari, " A Study on Credit Risk Management in Scheduled Banks", International Journal of Management (IJM), Volume 5, Issue 12, December (2014), pp. 79-89.

[33] Dr. C. Mahadeva Murthy and Prof. S.N. Pathi, " An Assessment of Risk Management in Banking Sector: A Study with Special Reference to Public and Private Sector Banks in India", International Journal of Advanced Research in Management (IJARM), Volume 4, Issue 3, September - December 2013.

[34] Farah Salwati Ibrahim and Muneera Esa, A Study on Enterprise Risk Management and Organizational Performance: Developer's Perspective, International Journal of Civil Engineering and Technology, 8(10), 2017, pp. 184-196. 